\title{
Evidence of active shortening along the eastern border of the San Rafael basement block: characterization of the seismic source of the Villa Atuel earthquake (1929), Mendoza province, Argentina
}

\author{
M. BRANELLEC*†,B. NIVIERE**,J.-P. CALLOT*，V. REGARD \\ \& J.-C. RINGENBACH $\S$ \\ * Université de Pau et des Pays de l'Adour, Laboratoires des Fluides Complexes et Leurs Réservoirs, Equipes \\ Geosciences, CNRS UMR 5150, Avenue de L'université, Pau, France \\ $\ddagger$ Université Paul Sabatier, Laboratoire Géosciences Environnement Toulouse (GET) 31400, France \\ $\S$ Total SA, Centre Scientifique et Technique Jean Féger, Avenue Larribau, Pau 64000, France
}

(Received 6 November 2015; accepted 25 February 2016; first published online 30 June 2016)

\begin{abstract}
On the 30 May 1929, a massive earthquake occurred in the San Rafael area (southern Mendoza province) leading to the destruction of the Villa Atuel and Las Malvinas towns. The region affected by the ground shaking covers a large part of southern South America. Although no surface breaks have been detected on the surface, several authors have pointed out active faults that could be related to the event of 1929. Using satellite imagery and field observations, we investigated two active faults situated on the eastern border of the San Rafael Block (SRB) close to or within the epicentral area. The most prominent faults are the $c .40 \mathrm{~km}$ long Las Malvinas and c. $30 \mathrm{~km}$ long Cerro Negro reverse faults which are located near the epicentral area. Geological and morphological observations allow us to describe late Pleistocene activity and estimate the long-term slip rates of these faults. Possible ruptures that match our observations and which are compatible with the cartographic length of these faults would account for a seismic moment magnitude of $M_{0}=2.8 \times 10^{19} \mathrm{~N} \mathrm{~m}$ and a moment magnitude of $M_{\mathrm{W}}=6.9$. The morphological signatures of these fault segments and the occurrence of the San Rafael earthquake suggests that the southern Mendoza Province is still currently submitted to shortening.
\end{abstract}

Keywords: active tectonics, San Rafael Block Argentina, cosmogenic dating, geomorphology.

\section{Introduction}

A strong seismic event occurred in the Argentine piedmont on 30 May 1929 (Costa et al. 2006). The epicentral area was the Villa Atuel and Las Malvinas towns, part of San Rafael suburbs, on the eastern border of the San Rafael basement block (Fig. 1). Strong shaking was widespread from as far away as $1000 \mathrm{~km}$ from the epicentral zone in Buenos Aires, leading to many casualties and causing much damages in the vicinity of the San Rafael city. No surface rupture was identified. Several potential fault sources were suspected within the epicentral region however, making it difficult to identify the fault segment responsible for the earthquake. At a larger scale, structural styles are well understood (Giambiagi et al. 2008; Folguera et al. 2009; Branellec et al. 2016) but strain rates are poorly constrained by only a few GPS studies (Kendrick et al. 1999; Khazaradze, 2003).

Using satellite imagery and published geological information, we compiled the main active faults within the epicentral region of the Villa Atuel earthquake. After a critical revision of earlier maps, we focused on the eastern border of the San Rafael block, delimited

$\dagger$ †uthor for correspondence: matthieu.branellec@gmail.com by the two most prominent faults in this area: the Las Malvinas and Cerro Negro faults. Based on geomorphological analysis and cosmogenic dating, we found evidence of recent tectonic activity along these fault segments and also quantified their long-term seismic hazard (slip rates, moment magnitude, maximum displacement and recurrence time). Finally, we discuss the large-scale tectonic implications in relation to the current dynamics of the Andean back-arc.

\section{Regional tectonics}

The 1929 earthquake occurred along the eastern border of the San Rafael Block (SRB) which is located $100 \mathrm{~km}$ eastwards from the Malargüe Fold-Thrust Belt (MFTB, Fig. 1). The main structural grain is highlighted by the topography and main rivers and streams, such as the Rio Atuel and Rio Diamante rivers. These directions follow a N-S-trending axis in the MFTB, passing to a NW-SE-aligned direction in the SRB.

From Late Cretaceous - Miocene times, the subduction of the Nazca plate beneath the South American plate triggered three shortening pulses that gave rise to a fold-thrust belt stage in the Andean retro-arc (Manceda \& Figueroa, 1995). Prior to its inversion, the SRB was already a topographic high situated at the 

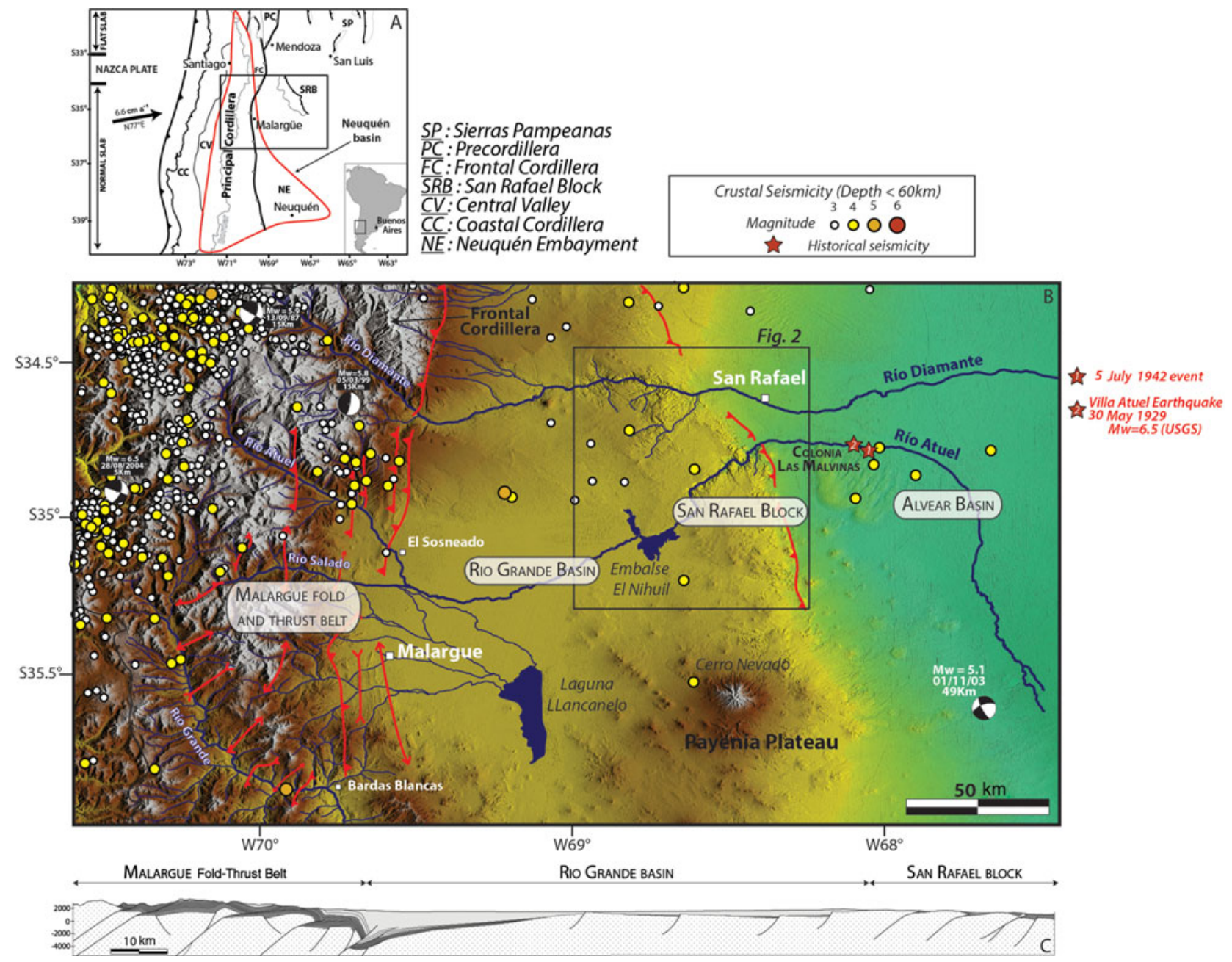

Figure 1. (a) Geodynamic setting of the Neuquén Basin showing the several morpho-structural units between $32^{\circ} \mathrm{S}$ and $40^{\circ} \mathrm{S}$. (b) Seismotectonic framework of the region hit by the 1929 earthquake. The plotted crustal seismicity $(<60 \mathrm{~km})$ has been taken from the USGS database and topography is derived from an ASTER GDEM $(30 \mathrm{~m})$. (c) Schematic cross-section running from the Malargue Fold-Thrust Belt to the San Rafael Block showing the global structural style characterized by the involvement of the pre-Jurassic basement (white: basement rocks; grey: Mesozoic and Cenozoic cover). Red stars refer to historical seismicity (unknown location of macroseismic epicentres).

easternmost edge of the Triassic syn-rift basins. The cross-section presented in Figure 1 runs from internal parts of the MFTB as far as the SRB. It can be described as follows. The MFTB mainly results from the crustal inversion of the borders of the ancient rift basins and from local shallow thin-skinned deformation related to basement thrust propagation into the cover. This inversion occurred during 75-55 Ma and 15-8 Ma (Giambiagi et al. 2008; Folguera et al. 2015). Nevertheless, G. Messager (unpub. PhD thesis, Université de Pau et des pays de l'Adour, 2010) showed that the mountain front submitted to shortening during Quaternary time. Further east, the Andean uplift was recorded in the Rio Grande palaeo-foreland basin which is filled with $2500 \mathrm{~m}$ of upper Mesozoic - Cenozoic sediments and was subsequently cannibalized when the SRB began to uplift (Fig. 1).

The SRB is mostly made up of several terranes accreted during Palaeozoic time along the southwestern margin of the Gondwana supercontinent known as the Rio de la Plata Craton (Ramos, 2010). The SRB consists of a middle-upper Proterozoic metamorphic base- ment covered by lower-middle Palaeozoic sediments, in turn unconformably overlain by Carboniferous continental and marine series. A widespread volcanic event then led to a thick accumulation of rift-related PermoTriassic volcanic and sedimentary rocks (Puesto Viejo Formation) known as the Choiyoi Group. The Miocene and Pliocene (Aisol Formation) sediments that partially cover the SRB are directly deposited on top of the Choiyoi Group rocks, confirming the existence of a long sedimentary hiatus spanning Late Triassic Miocene times (González Díaz, 1972; Forasiepi et al. 2011). The SRB is surrounded to the east by the Triassic Alvear (Fig. 1) and the d'Algarrobo del Aguila basins (Criado Roqué \& Ibañez, 1979; Kostadinoff \& Llambías, 2002).

By Miocene time, large amounts of arc-related lavas had emplaced on the eastern flank of the principal cordillera as well as that of the SRB, which is located more than $500 \mathrm{~km}$ from the Chile trench (Kay et al. 2006; Giambiagi et al. 2008). The volcanism subsequently shifted towards the SRB and the Rio Grande Basin during Pliocene-Pleistocene time (Bermúdez et al. 


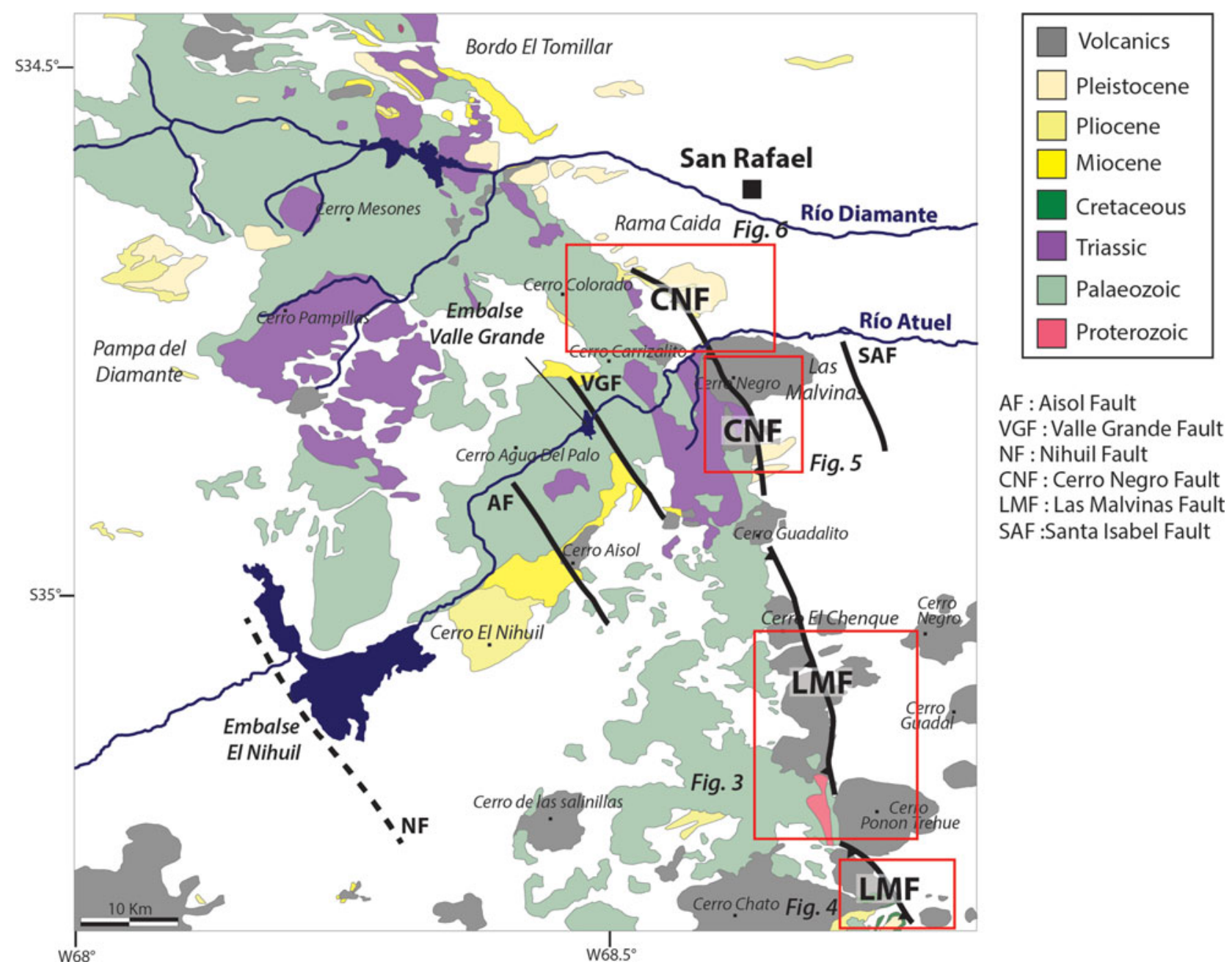

Figure 2. (Colour online) Geological map of the San Rafael Block, modified from Sepúlveda et al. (2000).

1993; Folguera et al. 2009), whereas only small volcanic bodies are found in the eastern part of the MFTB (Cortés \& Sruoga, 1998).

If it is now widely accepted that shortening governed the region from middle Cretaceous - early Miocene time, the current tectonic regime is still a matter of debate. Some authors suggest that the region is currently experiencing gravitational collapse in response to the increase in the slab-dip angle (Ramos \& Folguera, 2005; Folguera, Zapata \& Ramos, 2006; Lara \& Folguera, 2006; Ramos \& Kay, 2006; Folguera et al. 2007, 2008). Nonetheless, the onset of this extension and its associated magnitude and related mechanisms are not yet well constrained and so remain disputed. Some other authors propose that the region is still currently subjected to shortening (Cobbold \& Rossello, 2003; Galland et al. 2007; Guzmán, Cristallini \& Bottesi, 2007; Huyghe et al. 2015; Huyghe, Nivière \& Bonnel, 2015; Marques \& Cobbold, 2002; Messager et al. 2010, 2014).

\section{Local active faults}

A number of faults cutting through the SRB show morphologic signatures, easily identifiable from remote sensing analysis and fieldwork. Morphologies are characteristic of segmented thrust faults ranging between $10 \mathrm{~km}$ and $30 \mathrm{~km}$ long. In the northern part of the SRB, these faults mainly trend along a NNW axis cutting through the N-S-trending Palaeozoic structural grain, while southward they lie parallel to the $\mathrm{N}-\mathrm{S}$ direction. Several structural indications suggest a compressive tectonic activity on some fault segments (Bastias et al. 1993; Lucero, 2002; Costa et al. 2004, 2006). In particular, the Las Malvinas Fault has been considered as a possible source of the destructive Villa Atuel earthquake of 1929 although no surface break has been identified (Costa et al. 2006).

Among the four potentially active faults lying in the study area (Aisol, Valle Grande, Las Malvinas and Cerro Negro faults, Fig. 2), only the Las Malvinas and Cerro Negro faults show clear morphologic expression (Figs 1, 2) and are situated in the neighbourhood of the epicentral area. These faults lie along and delimit the eastern border of the San Rafael block (Cisneros, Ormeño \& Bastias, 1989; Bastias et al. 1993; Cisneros \& Bastías, 1993).The 40-45 km long Las Malvinas Fault can be divided into two segments trending approximately NNW-SSE and NW-SE, underlined by a monocline. The fault has not been observed at the 
surface and Costa et al. (2006) proposed that it is rooted on a $16 \mathrm{~km}$ deep décollement level. It is worth noting that Lupari et al. (2015) mentioned that the tectonic activity on this fault could account for the shallow crustal seismicity recently monitored in the region.

The Cerro Negro Fault is situated immediately north of the Las Malvinas Fault (Fig. 2). This fault segment is 25-30 km long and trends NNW-SSE (González Díaz, 1972). Along its northern termination the Cerro Negro Fault is highlighted by a $30 \mathrm{~m}$ high scarp in front of the San Rafael city. Southwards, the Cerro Negro Fault is underlined by a volcanic alignment (Fig. 2). Located $15 \mathrm{~km}$ east of the SRB, the west-facing $120 \mathrm{~m}$ high Santa Isabel scarp has been interpreted as the reactivated border of an extensional graben (Baker et al. 2009). Based on U-Pb dating performed on a pedogenetic carbonate which is cut by the fault, Baker et al. (2009) provided a minimum age of about $250 \mathrm{ka}$ for the last tectonic event registered on the Santa Isabel Fault.

Since they are located away from the epicentral area (Fig. 2), the Valle Grande and Aisol faults are unlikely to be responsible for the event of 1929. The Valle Grande Fault trends NW-SE and exhibits a clear morphologic signature in the Valle Grande area (Fig. 2). The Permian Tobas del Tesoro Misterioso Formation is cut by the fault and shows a $50 \mathrm{~m}$ long vertical offset (Costa et al. 2006). The Miocene Aisol Formation is found west of the Valle Grande Fault, whereas it is absent eastwards. Above the fault trace, volcanic lavas are brecciated and fractured and striated planes are visible trending $\mathrm{N} 320 / 72^{\circ} \mathrm{E}$ and $\mathrm{N} 321 / 58^{\circ} \mathrm{E}$, associated with slickenlines dipping at $27^{\circ}$ towards the NW (Costa et al. 2006). Kusiak (1993) has also documented the existence of several landslides and liquefaction figures that could be associated with the tectonic activity of an inverse fault lying N $340 / 67^{\circ} \mathrm{E}$. According to several authors this fault could account for major seismic events of magnitude higher than $M_{\mathrm{W}}$ $=5.7$. Nevertheless, some authors such as Folguera et al. (2009) interpreted this scarp as related to a normal fault.

The Aisol Fault, initially described by Lucero \& Paredes (1999) and Lucero (2002), lies in the northwestern part of the San Rafael Block (Fig. 2). It is expressed as a NW-SE-trending 15-20 km long discontinuous lineament (Fig. 2). In the northwestern part of the SRB the fault scarp reaches a maximum value of c. $100 \mathrm{~m}$ (Lucero, 2002). Recent evidence of tectonic activity along the Aisol Fault have been reported by several authors in the Cerro Aisol area (Lucero, 2002). These authors highlighted that Quaternary basaltic rocks are affected by right-lateral slip showing a lateral extent of at least $200 \mathrm{~m}$ with a $60 \mathrm{~m}$ high vertical offset. Based on recent satellite imagery, Costa et al. (2006) questioned the observation of Lucero (2002) and suggested that the deformation associated with the Aisol Fault could be related to gravitational collapse (e.g. the $34^{\circ} 56.4235^{\prime} \mathrm{S} ; 68^{\circ} 36.79^{\prime} \mathrm{W}$ site).

\section{Information relative to the earthquake of May 1929}

Within the epicentral area, the damage caused by the earthquake was reported some time after the main event by Lünkenheimer (1929). The earthquake was felt as far away as San Juan to the north, Buenos Aires to the east and Neuquén/Rio Negro to the south, injured 40 and caused the destruction of 32 houses in the Colonia Las Malvinas and Villa Atuel areas. The Pacifico railways were damaged and highly deformed in several places where screws were broken and railroad shoulders collapsed by up to $75 \mathrm{~cm}$ (Perucca \& Moreiras, 2006). In the Villa Atuel town, Lünkenheimer (1929) also described a number of warm-water seepages $\left(18^{\circ} \mathrm{C}\right)$ flowing towards the surface through the development of several metre-long and $4 \mathrm{~cm}$ wide fissures. Moreover, the water flow from many sources was observed to have significantly increased before the 30 May 1929 event (Lünkenheimer, 1929). The intensity of the Villa Atuel earthquake was estimated to reach VIII on the Mercali scale (Costa et al. 2006), but there is no accurate quantification of its magnitude. The magnitude value of $M_{\mathrm{W}}=6.5$ provided by Costa et al. (2006) matches the $M_{\mathrm{W}}=6.6$ value given by the USGS (NEIC-PDE), and the associated focal depth is $c .10 \mathrm{~km}$ (USGS). It has to be noticed that the maximum intensity was only of VIII while the earthquake was felt over a large area through Argentina, which suggest a strong-magnitude event. These two discrepant facts also indicate that the focal depth was probably higher than $10 \mathrm{~km}$. In the same region, a new destructive earthquake reached an intensity of VI on the Mercali scale on 5 July 1942.

\section{Geology and morphology of the Las Malvinas and Cerro Negro faults}

In this section we focus on both the Las Malvinas and the Cerro Negro faults and provide new evidence about their recent tectonic activity. Both of these faults separate the Proterozoic and Triassic terranes of the SRB to the west from the Quaternary Alvear Basin to the east (Fig. 2). The Alvear Basin is parallel to the eastern border of the SRB and is related to the south to a set of extensional Triassic basins partly shortened during the Andean Orogeny (Ramos \& Kay, 1991) and overlaid by syn-orogenic continental rocks deposited from Miocene time onwards. These fluvial deposits grouped into the Aisol Formation (González Díaz, 1972) have been accurately dated according to their vertebrate fossil content (Forasiepi et al. 2011). At the large scale, these syn-orogenic deposits form a long and gently west-dipping monocline (Fig. 1).

\section{5.a. Las Malvinas Fault segments}

The Las Malvinas Fault can be divided into two major segments (Fig. 2) that trend NNW-SSE for the $30 \mathrm{~km}$ long northern segment and NW-SE for the $12 \mathrm{~km}$ long southern segment. This fault corresponds to a 


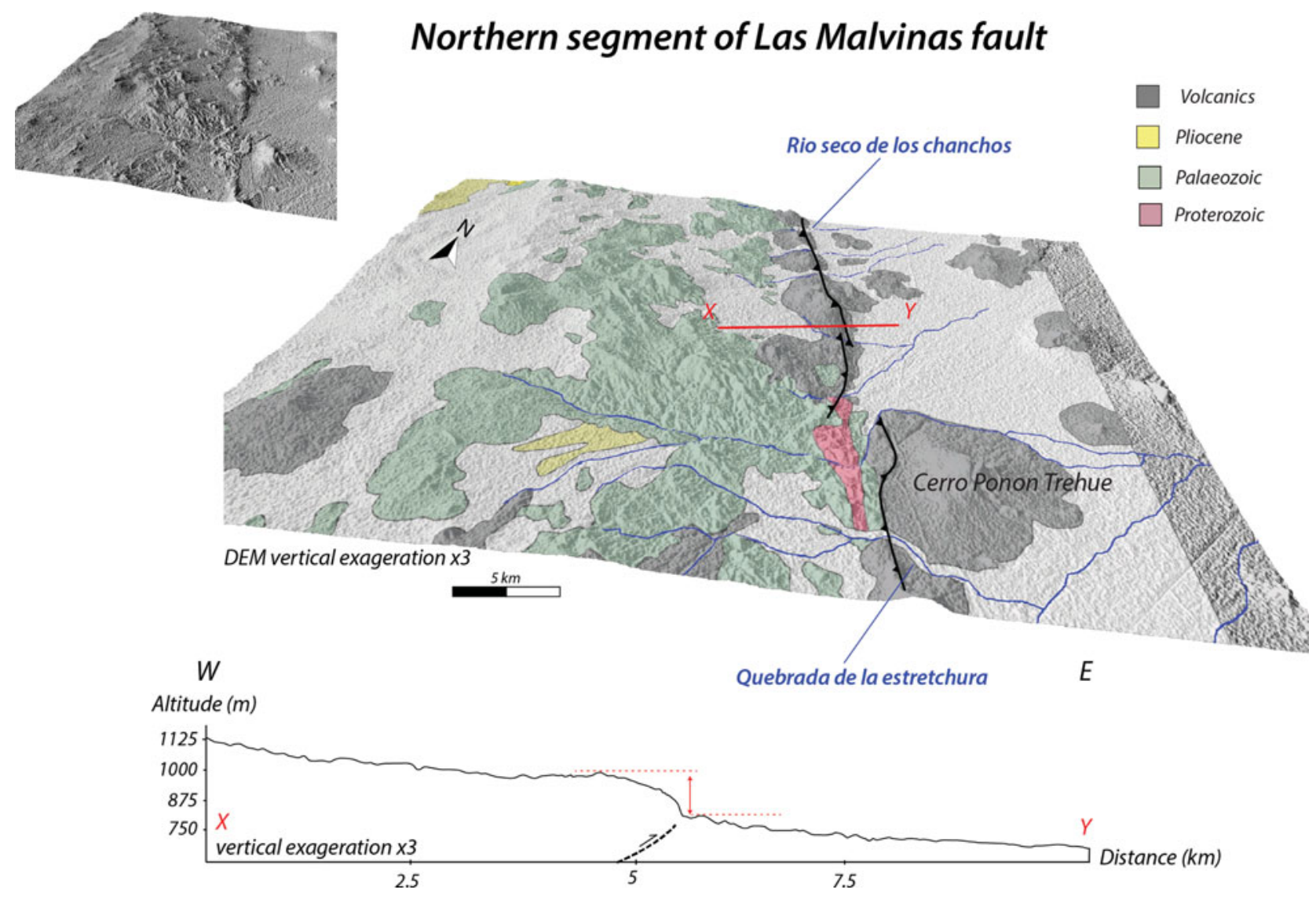

Figure 3. Upper: 3D view of the northern part of the Las Malvinas fault. Located on Figure 2. Lower: topographic profile along the eastern border of the SRB showing a 100-150 m high topographic ridge above the cartographic trace of the fault.

$100-150 \mathrm{~m}$ high ridge if excluding Quaternary lavas that have emplaced recently. The Las Malvinas Fault also delimits an immature regressive erosion front, suggesting a recent reactivation of the escarpment. In several places the upper Pliocene - lower Pleistocene lavas are folded above the main scarp, also suggesting a recent tectonic activity on this fault (Fig. 3). In the Cerro Ponon Trehue area (Fig. 3) the upper Pliocenelower Pleistocene lava flow (Coyocho Formation of the Chapua Group) directly lies on the Carboniferous El Imperial Formation that exhibits dip angles ranging of 44-71 ${ }^{\circ}$ above the main fault scarp. Costa et al. (2006) have documented the existence of striated fault planes along bedding surfaces which they interpreted as being related to flexural slip processes developed during folding of the lavas.

In the Quebrada de la Estrechura valley (immediately south of the Cerro Ponon Trehue), the progressive increase of the dip angle of the lava flow $\left(28-45^{\circ}\right)$ also suggests the presence of a fold hinge above the main morphological trace of the fault. Such a lava flow deformation pattern could also result from the covering of a pre-existing escarpment, suggesting that the fault was not necessarily recently reactivated. This interpretation is not supported by the fold-related flexural slip evidence or the extrados fractures observed in the field (Costa et al. 2006), which are consistent with folding and shortening along the eastern border of the SRB. Moreover, east of the Cerro Negro in the Rio Seco de los Chanchos valley, Costa et al. (2006) indicate a 2-3 $\mathrm{m}$ high vertical offset in the Pleistocene Maipo Formation. Several earthquakes, including the event of 30 May 1929, have been attributed to the Las Malvinas Fault (Cisneros, Ormeño \& Bastias, 1989; Bastias et al. 1993; Cisneros \& Bastías, 1993). The Quaternary coseismic slip has been interpreted to be normal and left-lateral according to Cisneros \& Bastias (1993), whereas Costa et al. (2004) considered it as reverse by showing active shortening along the eastern SRB border. South of the Ponon Trehue Volcano on the southern segment of the Las Malvinas Fault, the Rio Secos los Toldos has incised the frontal escarpment making it a natural trench (Fig. 4). The river erosion exposes the Upper Cretaceous conglomerates of the Punta del Agua Formation (Fig. 4) in the upstream direction, overlaid by the lower Pliocene alluvium. On both sides of the valley, the Cretaceous units are covered by the Grupo Chapua basalts of late Pliocene - early Pleistocene age (Fig. 4). To the west, these rocks lie horizontally on top of the Cretaceous units, whereas in the vicinity of the main fault segment volcanic rocks are dipping at $60^{\circ}$ towards the east. Flowing through the substratum, the Rio Seco Los Toldos dug a valley across the ridge. Intercalated between the Plio-Pleistocene lavas and the valley floor, the remnant of an alluvial terrace disappears downstream with respect to the morphological trace of the fault. This level can be interpreted as a remnant of the former watercourse, which has been 


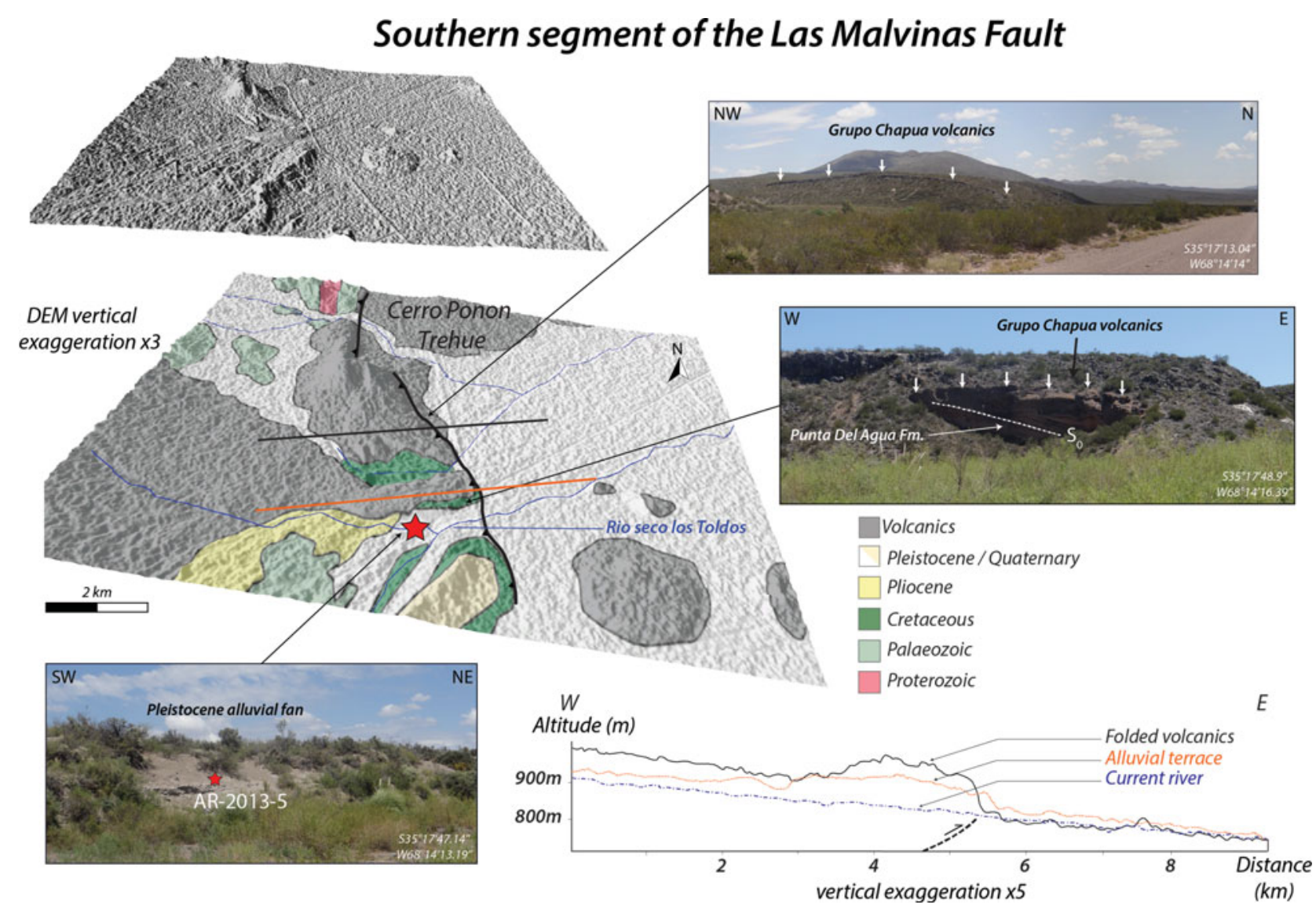

Figure 4. 3D view of the southern segment of the Las Malvinas fault. Located on Figure 2. Right: field pictures exhibiting the folding of Chapua Group volcanic (Pleistocene) rocks above the fault trace. Lower: topographic profiles highlighting the uplift of the alluvial terrace as well as the Chapua Group volcanic rocks. Left: field picture showing the location of the terrace-related sampled pebbles for cosmogenic dating.

subsequently uplifted by $c .15 \mathrm{~m}$ by the fault. Deeply incised by the river below the Pleistocene lavas, this alluvium level corresponds to the most recent geomorphological marker of deformation. We sampled it to perform cosmogenic nuclide dating. A few kilometres south, the Grupo Chapua lavas exhibit the same type of morpho-structural configuration above the fault trace (northernmost part of Fig. 3).

\section{5.b. Cerro Negro Fault segments}

North of the Las Malvinas Fault between the Rio Atuel and the Rio Diamante, González Díaz (1972) identified the Cerro Negro Fault based on the identification of both a chain of aligned volcanoes to the south and an east-facing escarpment, trending NNW-SSE to the north, near the San Rafael city (Fig. 2). To our knowledge the only available evidence of recent deformation is provided by the work of Folguera et al. (2009) at the foot of the Cerro Negro on the southernmost segment of the Cerro Negro Fault. The Palaeozoic El Imperial and Triassic Choiyoi formations are covered by the Cerro Negro lavas (Chapua Formation) dated at $0.801 \pm 0.049 \mathrm{Ma}$ by Folguera et al. (2009). The lava flows draw up an anticline located above the fault trace that some authors interpret as an evidence of reverse faulting which occurred by post-middle Pliocene time
(Fig. 5). The E-W-trending topographic profile presented in Figure 5 immediately north of the Cerro Negro Volcano exhibits a 100-125 m high topographic ridge which is compatible with the location of the reverse fault documented by Folguera et al. (2009). The fault segment displays a continuous trace northwards in the southwestern San Rafael suburbs, a region free of the inherent problem to consider lava flows as deformation markers (lava flowing above a pre-existing escarpment v. lava flows subsequently deformed). Towards the northwestern part of the Cerro Negro Fault, a young tectonic marker is observed south of the Rama Caida area (Figs 2, 6). The fault scarp is marked by a $20 \mathrm{~m}$ high topographic ridge we can follow for up to $7 \mathrm{~km}$ towards the NW. On the top on the ridge lie the lower Pliocene alluviums of the Rio Seco del Zapallo Formation overlain by the La Invernada Formation alluvial fan of middle Pleistocene age (San Rafael geological map; González Díaz, 1972).

The western part of the ridge (Fig. 6) comprises Holocene alluviums that are widely represented in the study area; they also cover the north and east part of the topographic ridge (Figs 2, 6). The ridge formed a topographical barrier for the several watercourses draining the San Rafael Block. Indeed, based on remote sensing analysis and fieldwork, we note that all the rivers abut on the topographic ridge and are deviated 


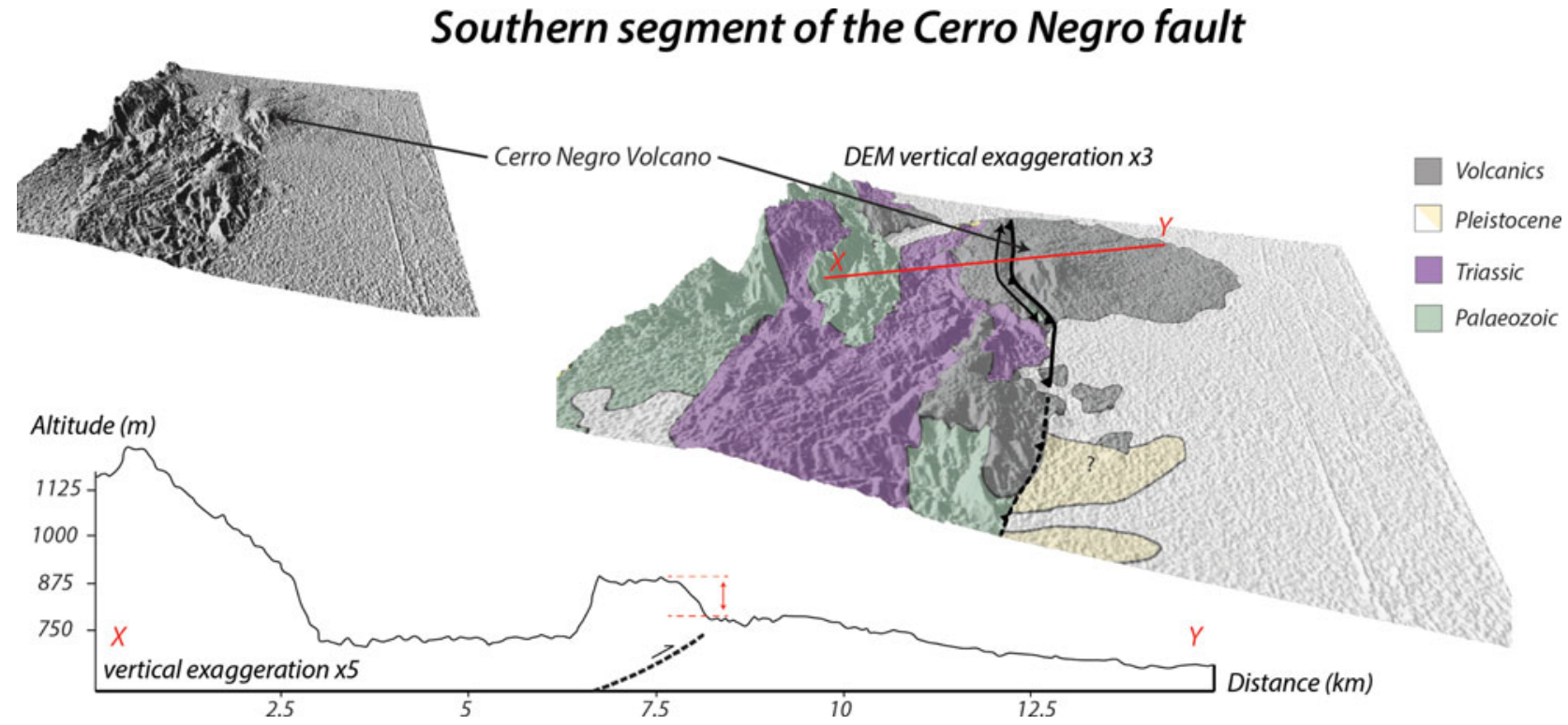

Figure 5. 3D view of the southern segment of the Cerro Negro Fault. Below, topographic profile showing the topographic ridge situated at the foot of the Cerro Negro Volcano and related to the Cerro Negro Fault initially described by Folguera et al. (2009). This zone characterizes the transition between the Las Malvinas and the Cerro Negro faults.

\section{Northern segment of the Cerro Negro fault}
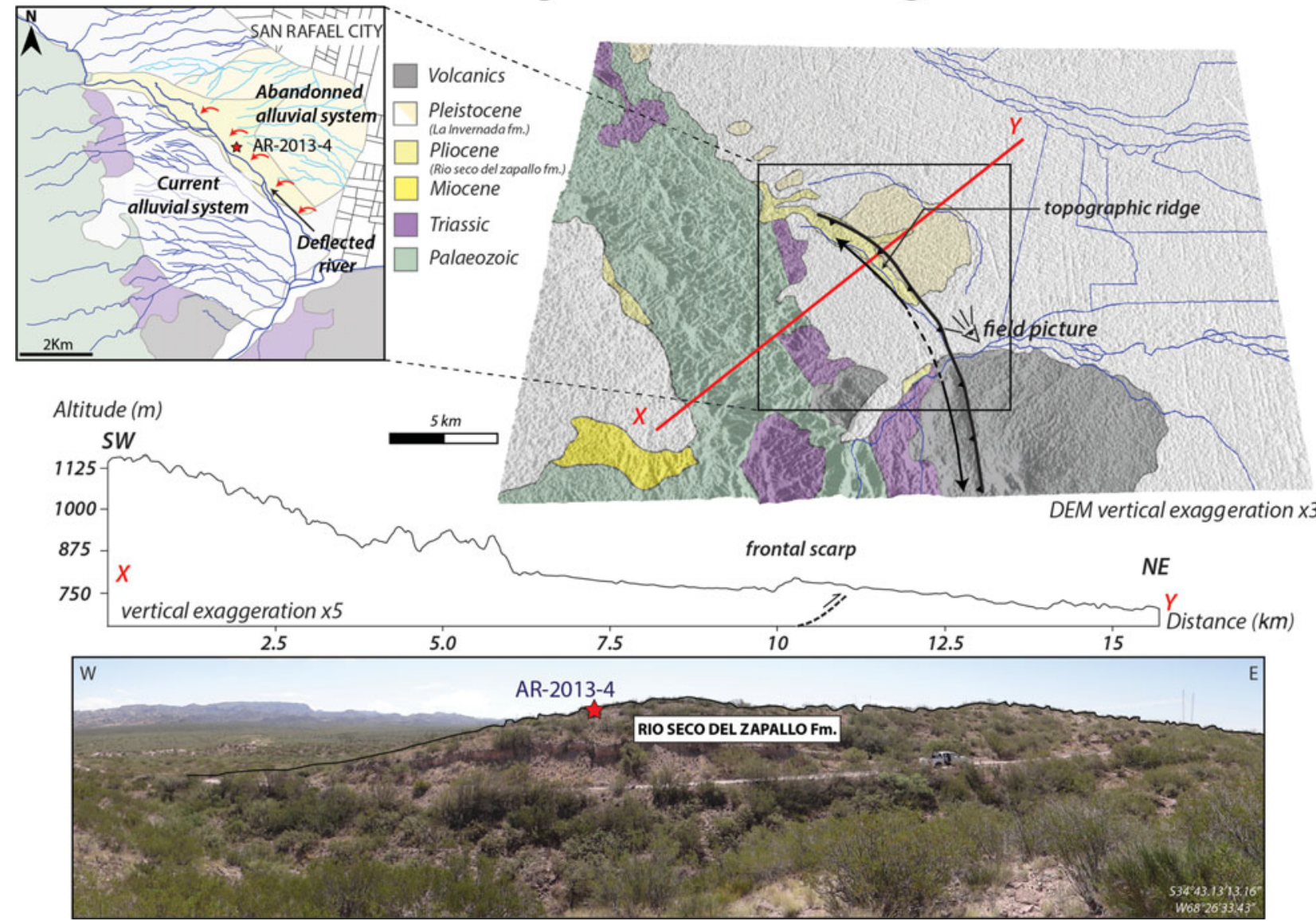

Figure 6. 3D geological view of the northern segment of the Cerro Negro Fault. The Plio-Pleistocene topographic ridge is associated with the growth of an anticline that triggers reorganization of the drainage network we can observe to the left part of the figure. Lower: topographic profile and field picture showing the anticline hinge in the Plio-pleistocene alluviums. The AR-2013-4 has been sampled on the top of the topographic ridge for cosmogenic dating. 
Table 1. AMS ASTER ${ }^{10} \mathrm{Be}$ concentration measurements.

\begin{tabular}{lcccccccccc}
\hline Sample & $\begin{array}{c}\text { Latitude } \\
(\mathrm{S})\end{array}$ & $\begin{array}{c}\text { Longitude } \\
(\mathrm{W})\end{array}$ & $\begin{array}{c}\text { Elevation } \\
\text { (m asl) }\end{array}$ & $\begin{array}{c}\text { Mass dissolved } \\
\text { quartz }(\mathrm{g})\end{array}$ & $\begin{array}{c}\text { Spike } \\
{ }^{9} \mathrm{Be}(\mathrm{mg})\end{array}$ & $\begin{array}{c}\text { Spike } \\
{ }^{9} \mathrm{Be}(\text { atoms })\end{array}$ & $\begin{array}{c}{ }^{10} \mathrm{Be} /{ }^{9} \mathrm{Be} \\
\left(10^{-15}\right)\end{array}$ & $\begin{array}{c}{ }^{10} \mathrm{Be} \\
(\text { atoms } / \mathrm{g})\end{array}$ & $\begin{array}{l} \pm \\
\pm\end{array}$ \\
\hline AR2013-4 & -34.7199 & -68.4427 & 780 & 5.62 & 100.02 & $2.022 \mathrm{E}+19$ & 120.01 & 5.60 & 424966 & 20276 \\
AR2013-5 & -35.2989 & -68.2387 & 845 & 5.51 & 100.53 & $2.032 \mathrm{E}+19$ & 117.87 & 6.08 & 428125 & 22565 \\
\hline
\end{tabular}

AMS Standard: in house BeO STD- $11,{ }^{10} \mathrm{Be} /{ }^{9} \mathrm{Be}=(1.191 \pm 0.0109) \times 10^{-11}$.

southwards where they meet one of the Rio Atuel tributaries. The presence east of the ridge of former alluvial fans of the La Invernada Formation (Sepúlveda et al. 2000) that was fed from the west shows that the present drainage configuration is recent. Indeed, the rivers previously flowed eastwards without any obstacle because the topographic ridge did not yet exist. In the field, we found a channel within the Rio Seco del Zapallo Formation on top of the ridge showing an anticlinal shape (Fig. 6). These observations support the fact that the topographic ridge is related to the formation of an anticline, which developed after the deposition of the clastics of the La Invernada Formation that lies above the Rio Seco del Zapallo Formation. The progressive uplift of the ridge induced a deviation and reorganization of the drainage network in the southeastern direction (Fig. 6). The anticline was therefore formed after middle Pleistocene times. We sampled several pebbles at the surface of the topographic ridge to perform cosmogenic nuclide dating. All these forms of geomorphological evidence are proof of a recent activation of the northern segment of the Cerro Negro Fault, which is compatible with the interpretation provided by Folguera et al. (2009). Our observations also suggest that the cartographic trace of the active fault segment has to be shifted some kilometres westwards compared to the topographic front.

\section{Cosmogenic nuclide dating}

Cosmogenic nuclides produced in situ (also called terrestrial cosmogenic nuclides or TCN) are commonly used to date surface exposure of rocks, sediments and, among them, alluvial terraces. We sampled both the fluvial terrace of Rio Seco Los Toldos (AR-2013-5) and the Rio Seco del Zapallo Formation (AR-2013-4) for ${ }^{10} \mathrm{Be}$ and ${ }^{26} \mathrm{Al}$ analysis of quartz. On both sites, five pebbles of diameter 10-15 cmwere sampled at the surface; the shielding is negligible. Due to an error during the process, all the samples from the same site were crushed and mixed together. Pebble lithology is quartzite for AR-2013-4 and rhyolite for AR-20135. The samples have been prepared and measured at CEREGE (Aix-Marseille University; AMS ASTER facilities). Their concentrations were normalized to inhouse standards (Tables 1 and 2).

${ }^{10} \mathrm{Be}$ concentrations are similar for the two sites; they therefore indicate probable similar exposure ages. Table 2 provides the exposure ages considering several denudation rates: $0,1,5$ and $10 \mathrm{~m} \mathrm{Ma}^{-1}$. As given by the various production models for zero erosion, the expos- ures ages are c. $61 \pm 6 \mathrm{ka}(\mathrm{AR}-2013-4)$ and $57 \pm 6 \mathrm{ka}$ (AR-2013-5). It must be noted here that exposure ages are not linearly dependent on erosion rates. On alluvial formations sampled with care on horizontal surfaces, in arid environments and particularly in the study area, the erosion is usually low and most of the evaluations range over 0-1 $\mathrm{m} \mathrm{Ma}^{-1}$, possibly extending up to $10 \mathrm{~m} \mathrm{Ma}^{-1}$ (Baker et al. 2009; Portenga \& Bierman, 2011; Pepin et al. 2013; Siame et al. 2015). In comparable climatic conditions, Siame et al. (2015) reported erosion rates lower than $5 \mathrm{~m} \mathrm{Ma}^{-1}$. We consider that it is likely to be the maximum value in the study area. In that case the exposure ages of the AR-2013-4 and AR-2013-5 samples become, respectively, $78 \pm 10 \mathrm{ka}$ and $72 \pm 10 \mathrm{ka}$. It is noticeable that Baker et al. (2009) found a similar age (66-69 $\pm 15 \mathrm{ka})$ for an alluvial terrace along the Rio Diamante $c .100 \mathrm{~km}$ upstream, which they attribute to a major episode of aggradation. Consequently, exposure ages indicate a common age for AR-2013-4 and AR-2015-5 of $c$. $60 \mathrm{ka}$ with no erosion and c. $80 \mathrm{ka}$ with a $5 \mathrm{~m} \mathrm{Ma}^{-1}$ denudation rate.

\section{Discussion}

\section{7.a. Quantification of fault slip rates}

We do not focus on the Valle Grande and Aisol faults for the following reasons: on one hand they are located out of the maximum intensity zone (VIII), and on the other hand the evidence of possible Quaternary activity along these segments is not as clear as along the eastern border of the SRB. The Cerro Negro and Las Malvinas faults show clear evidence of recent activity within the epicentral zone of the Villa Atuel earthquake. These faults are $25-45 \mathrm{~km}$ long and so are compatible with the macroseismic intensity of the earthquake. The sinuous cartographic traces of the faults as well as the folding associated with fault traces do not indicate normal faulting processes. That is why the interpretation of Costa et al. (2006) in which the escarpments and related features are indicative of reverse faulting appears to be more suitable here. As neither surface rupture nor fault emergence was recognized after the main shock (Costa et al. 2006) the earthquake is likely to have occurred on a blind fault, which is a common feature of compressive domains (Stein \& Yeats, 1989).

The observed fold wavelength of the alluvial terrace above the Las Malvinas southern fault segment (Fig. 7) is lower than $3 \mathrm{~km}$ and does not scale the eastern border of the SRB where the fault segments are 


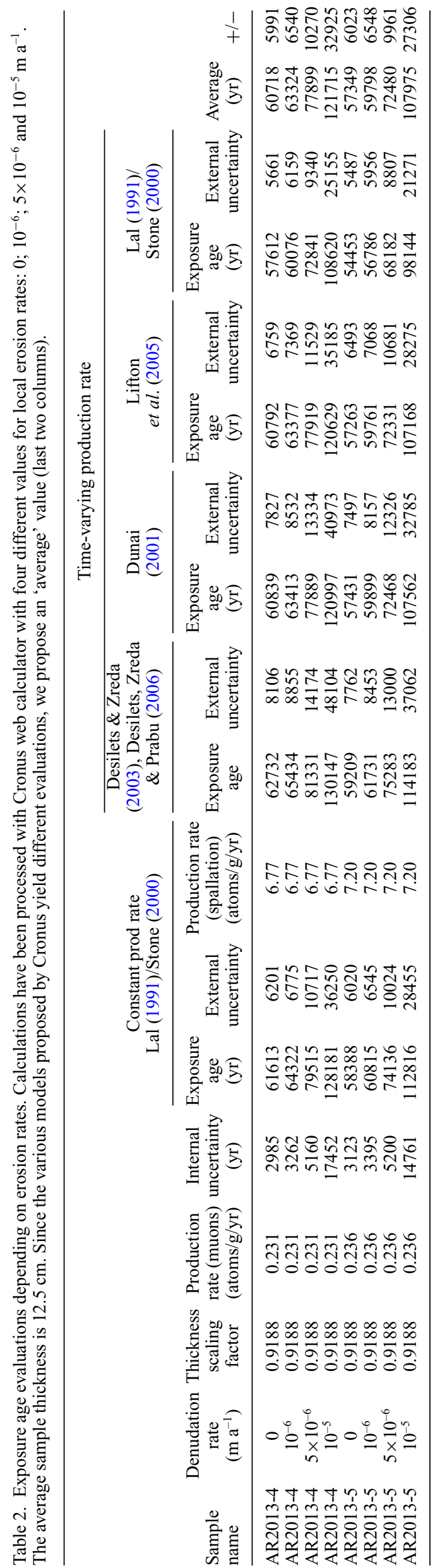

of crustal scale. Indeed, each fault segment is at least $10 \mathrm{~km}$ long. Costa et al. (2006) postulated that the Las Malvinas Fault is rooted at $16 \mathrm{~km}$ at depth. If we consider the observed fold wavelength, this structure is likely to be produced above a shallower décollement level probably not deeper than $4 \mathrm{~km}$. Our observations and those discussed previously (see Section 3 ) are fundamental because they show that the reported fault activity is not directly linked to the crustal deformation front of the SRB that accommodates the Andean shortening. The active deformation is shifted forwards with respect to the crustal deformation front, which is a classical scheme we can find in growing mountain belts. Consequently, this deformation may be interpreted as a secondary and shallow effect of the deepseated blind thrusting responsible for the Villa Atuel earthquake.

Since we are dealing with a progressive and immature deformation, fault propagation fold models are often preferred in such setting (Simoes et al. 2007). Based on the fault propagation fold model Erslev (1991) proposed use of the trishear fold model, according to which the fault is propagating through a triangular zone of distributed shear. A wide field of velocity and shape of the triangular zone can be generated by changing the $\mathrm{P} / \mathrm{S}$ (propagation of the fault/slip on the fault) ratio that determines the velocity by which the fault tip propagates with respect to the total slip accommodated on the fault (Allmendinger, 1998; Allmendinger \& Shaw, 2000; Zehnder \& Allmendinger, 2000). Unfortunately our geomorphological field observations above the Las Malvinas and Cerro Negro faults do not provide the geological constraints we needed to perform a structural modelling of those structures. An alternative approach could be one based on the folding model of Bernard et al. (2007). During folding these authors observed that internal strain is accommodated through distributed pure shear until a ramp is formed where further deformation is able to localize. Based on the field velocity, Bernard et al. (2007) provide a simple analytical expression of incremental vertical and horizontal velocity fields. Implementation of this model however requires geological markers at depth, or at least the depth of the décollement level controlling the development of the structure, which we do not have since we lack seismic or borehole data. This implies that it will be difficult to quantify the shortening accommodated by these structures.

However, Folguera et al. (2009) dated the lava flow at the foot of the Cerro Negro, and we dated a deformed terrace and alluvial fan above the fault traces; we therefore have three deformation markers of different ages. On the basis of these ages $(t)$ and on the amplitude $(A)$ of folding in the terrace remnant and in the alluvial fan, we can easily quantify the uplift rate $(U)$ above these structures: $U=A / t$. If we assume no internal strain in the sedimentary cover, the slip rate $(S)$ above the underlying fault can be estimated by $S$ $=U / \sin d$ where $d$ is the fault dip angle. Considering our assumptions, we should consider here the or- 


\section{Las Malvinas fault - southern segment}
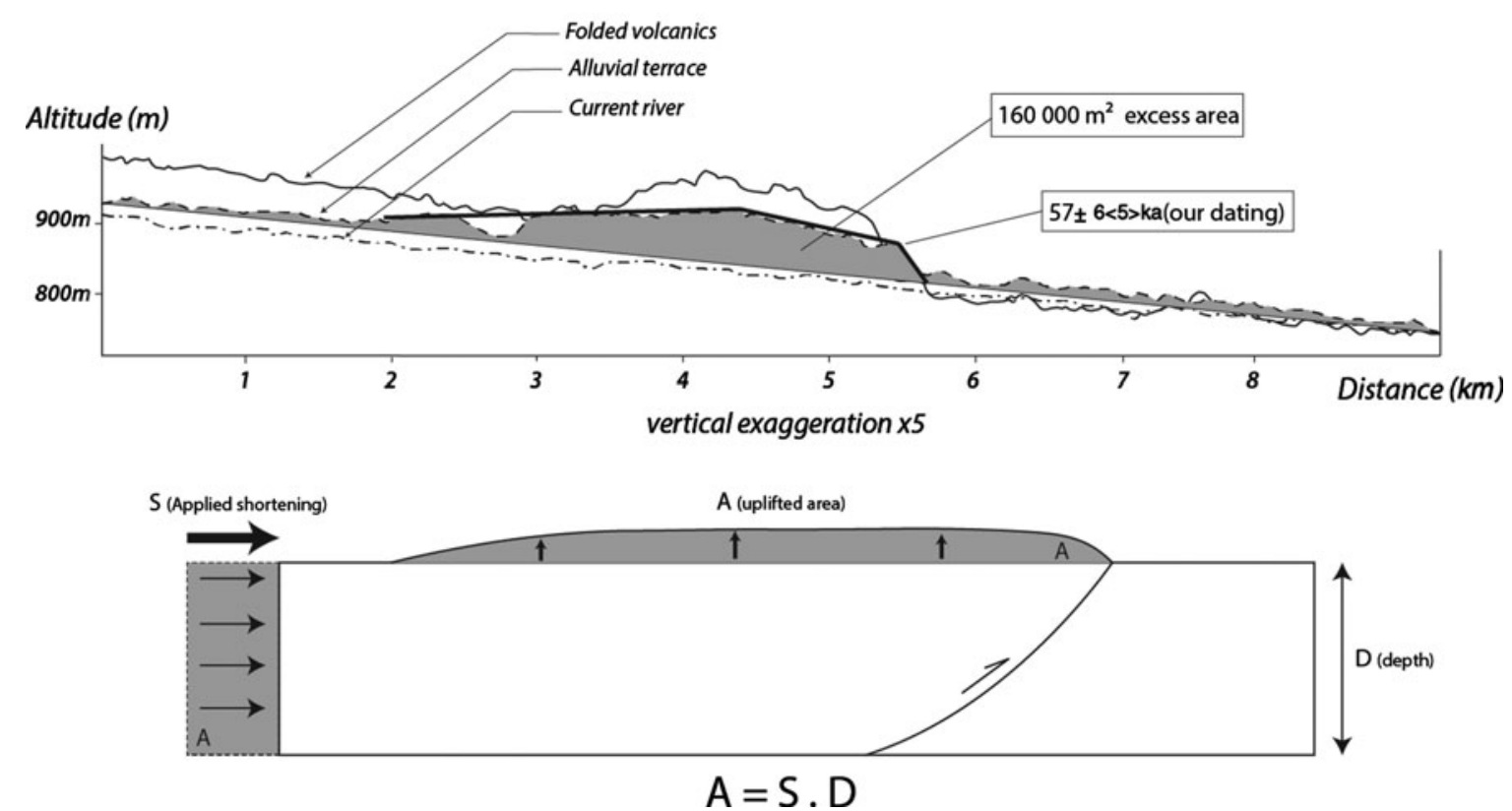

Figure 7. Topographic profile showing the excess area resulting from the terrace uplift related to the activation of the Las Malvinas southern fault segment. Simple model showing the relationships between the shortening, the uplifted surface and the depth to the décollement level.

Table 3. Calculation of the uplift and slip rates associated with the La Malvinas and Cerro Negro faults, based on cosmogenic analysis. The denudation rate is $0 \mathrm{~m} \mathrm{Ma}^{-1}$.

\begin{tabular}{lcccc}
\hline Faults segment & Fold amplitude $(\mathrm{m})$ & Age $(\mathrm{ka})$ & $U$, uplift $\left(\mathrm{mm} \mathrm{a}^{-1}\right)$ & $S$, slip rate above the fault $\left(\mathrm{mm} \mathrm{a}^{-1}\right)$ \\
\hline Las Malvinas South (AR-2013-5) & $75 \pm 5$ & $57 \pm 6$ & $1.31 \pm 0.22$ & $2.23 \pm 0.60$ \\
Cerro Negro North (AR-2013-4) & $90 \pm 10$ & $61 \pm 6$ & $1.47 \pm 0.31$ & $2.50 \pm 0.78$ \\
\hline
\end{tabular}

Table 4. Calculation of the uplift and slip rates associated with the La Malvinas and Cerro Negro faults, based on cosmogenic analysis. The denudation rate is $5 \mathrm{~m} \mathrm{Ma}^{-1}$.

\begin{tabular}{lcccc}
\hline Faults segment & Fold amplitude $(\mathrm{m})$ & Age $(\mathrm{ka})$ & $U$, uplift $\left(\mathrm{mm} \mathrm{a}^{-1}\right)$ & $S$, slip rate above the fault $\left(\mathrm{mm} \mathrm{a}^{-1}\right)$ \\
\hline Las Malvinas South (AR-2013-5) & $75 \pm 5$ & $72 \pm 10$ & $1.04 \pm 0.21$ & $1.77 \pm 0.54$ \\
Cerro Negro North (AR-2013-4) & $90 \pm 10$ & $78 \pm 10$ & $1.15 \pm 0.28$ & $1.96 \pm 0.68$ \\
\hline
\end{tabular}

der of magnitude rather than the absolute value of our results.

Tables 3 and 4 lists the results of our calculations above the southern segment of the Las Malvinas Fault (using the terrace remnant) and above the northern segment of the Cerro Negro Fault (using the alluvial fan), corresponding to denudation rates of 0 and $5 \mathrm{~m}$ $\mathrm{Ma}^{-1}$, respectively. The uncertainty on the amplitude of folding is due to the erosion in the western part of the ridge that withdrew the western limb of the fold. The calculated slip rates range from $2.23 \pm 0.6$ to 1.77 $\pm 0.54 \mathrm{~mm} \mathrm{a}^{-1}$ for the southern Las Malvinas Fault segment, and from $2.50 \pm 0.78$ to $1.96 \pm 0.68 \mathrm{~mm}$ $\mathrm{a}^{-1}$ for the northern Cerro Negro Fault segment. These values are consistent with those proposed by Costa et al. (2015) north of the study area, in the Precordillera region.

Given the fact that the fold shape is better constrained on the southern segment of the Las Malvinas Fault, the obtained results are supported by the application to that fold of the excess area method (Chamberlin, 1910; Epard \& Groshong, 1993; Moretti \& Callot, 2012). The conservation of mass implies that the area $A$ below a deformed level at an initial altitude $D$ above the décollement equals the product $D \times S$, where $S$ is the average total shortening of the layers below the considered horizon (Fig. 7). In practice, the shaded area in Figure 7 should equate the rectangle to the left. Since we analysed shallow deformation and assumed a décollement level rooted at $4 \mathrm{~km}$, we obtained an average total shortening of c. $40 \mathrm{~m}$ and an associated shortening rate of c. $0.6 \mathrm{~mm} \mathrm{a}^{-1}$ for the last $65 \mathrm{ka}$ on this structure. The deeper the décollement level, the lower the shortening rates (e.g. $0.47 \mathrm{~mm} \mathrm{a}^{-1}$ for a décollement at $5 \mathrm{~km}$ ).

\section{7.b. Estimation of the seismogenic potential}

This part of the paper aims to evaluate the seismogenic potential of the Las Malvinas and Cerro 
Table 5. Seismic parameters for the various fault segments. MFL: morphologic fault length; RLD: rupture length at depth; $M$ : moment magnitude of the maximum possible earthquake.

\begin{tabular}{lccccc}
\hline Fault segment & MFL $(\mathrm{km})$ & RLD $(\mathrm{km})$ & $M$ & Maximum displacement $(\mathrm{m})$ & Recurrence time $(\mathrm{yr})$ \\
\hline Las Malvinas S & 12 & 16.00 & $6.284 \pm 0.18$ & 0.96 & 520 \\
Las Malvinas N & 30 & 40.00 & $6.877 \pm 0.18$ & 1.42 & 1.02 \\
Cerro Negro S & 14 & 18.67 & $6.384 \pm 0.18$ & 0.96 & 440 \\
Cerro Negro N & 12 & 16.00 & $6.284 \pm 0.18$ & \\
\hline
\end{tabular}

Negro faults based on their morphologic expression. Considering the surficial total length of the fault segments, we evaluate the moment magnitude that they are likely to produce following the relationship of Wells \& Coppersmith (1994) whereby the moment magnitude $M$ depends on the fault length at depth (RLD in km) as follows:

$$
M=a+b \log \mathrm{RLD} .
$$

The coefficients $a$ and $b$ depend on the kinematic of the faults (we consider here reverse faulting) with $a=$ $4.49 \pm 0.11$ and $b=1.49 \pm 0.09$ (Wells \& Coppersmith, 1994). As the faults are blind, we cannot directly estimate the total rupture length at depth. We therefore evaluate this rupture length on the basis of the morphologic signature of the fault segments following Wells \& Coppersmith (1994): the rupture length to the surface generally represents $75 \%$ of the total rupture length at depth. This is based on the assumption that the fault is able to break along the entire segment, and this value corresponds to the maximum possible magnitude.

The maximum displacement (MD in $\mathrm{m}$ ) on a fault plane during the earthquake is linked to the moment magnitude $M$ by the relationship (Wells \& Coppersmith, 1994):

$$
\log \mathrm{MD}=a+b M
$$

where $a=-1.84 \pm 1.14$ and $b=0.29 \pm 0.17$ for reverse faulting. Considering the slip rate $(s)$ calculated in the previous section and considering a characteristic behaviour of the fault, we can at least approximate the maximum possible recurrence time of the earthquake dividing the maximum displacement (MD) by $s$.

Table 5 lists the results obtained for each fault segment assuming that the rupture concerned both segments of each fault. The estimation of the magnitude is consistent with the macroseismic observations realized after the main shock of 1929 by Stappenbeck (see Costa et al. 2006). These data are compatible with the observations and conclusion of Costa et al. (2006), in which they proposed that the Las Malvinas Fault is responsible for the Villa Atuel earthquake of 1929. On the basis of our data, we discard the Cerro Negro Fault as a possible source of the main event since it is located further from the epicentral area. In addition, it also represents a limited seismogenic potential in the case of major earthquake occurrence.

\section{7.c. Geodynamic implications}

Our observations have also provided new insights into the current geodynamics of this region. According to Ramos \& Folguera (2005), Lara \& Folguera (2006), Ramos \& Kay (2006) and Folguera et al. (2008), the study area is currently submitted to a generalized extension. An episode of back-arc magmatism established in the vicinity of the Payun Volcano at 4 Ma (Kay, 2002; Kay et al. 2006) is assumed to be related to the development of extensive basins in the Principal Cordillera (Folguera et al. 2009). This volcanism is thought to be associated with the retreat of the volcanic arc by up to $300-500 \mathrm{~km}$ towards the trench in response to a slabsteepening stage (Kay, 2002; Ramos \& Kay, 2006). This process led to the formation of an asthenospheric flow that induced crustal melting and attenuation (Folguera et al. 2007) as well as crustal collapse (e.g. Ramos \& Kay, 2006). Messager et al. (2014), Sagripanti et al. (2015) and Gürer et al. (2016), among others, provided new evidence that favours the hypothesis of ongoing shortening rather than extension. Finally, G. Messager (unpub. PhD thesis, Université de Pau et des pays de l'Adour, 2010) documented active deformation in the frontal zone of the Malargue Fold-Thrust Belt in the El Sosneado area. Deformed alluvial fans and folded terraces of the Rio Atuel River show clear evidence of shortening. All these geomorphological markers have been dated and provide a Pleistocene age, which corresponds to the latest event of reverse faulting is this area. Our observations confirm the conclusions of those authors which suggest that the Central Andean system is still under compression.

As the eastern border of the SRB is striking NW-SE to NNW-SSE, and taking into account that the current shortening in this area is roughly trending $\mathrm{E}-\mathrm{W}$, a leftlateral component of displacement could be expected along the eastern SRB border. The fact that the Las Malvinas and Cerro Negro faults both show right and left steps and bends (Fig. 2) seems incompatible with any strike-slip component. In addition, the Aisol and Valle Grande faults appear more linear and strike-slip deformation has been reported along these faults. The shortening component of deformation could therefore be accommodated along the eastern border of the SRB and the lateral component by the linear faults of the SRB interior.

Far-field compression in foreland cratonic setting is not an uncommon pattern of the deformation style, particularly in cordilleran back-arc setting (Hardebol et al. 2009). For instance, the foreland of the Rocky Mountains is well known for the building of the 
Laramide inversion arches during Palaeocene and Eocene time in the foreland of the Sevier Fold-Thrust Belt (Stone, 1993) through the development of crustalscale inversion far away from the fold-thrust belt front (DeCelles, 2004; Hardebol et al. 2009). Several mechanisms of far-field stress transmission from the deformation front to the apparently undeformed foreland basin have been envisioned (e.g. DeCelles, 2004; Jones et al. 2011). Among them are: (1) the existence of a lower detachment in which compressive features are rooted, and which should be localized in the crust at the ductile/fragile transition (see Ramos et al. 2004); (2) mid-crustal flow and lower crust thickening (e.g. McQuarrie \& Chase, 2000); (3) lithospheric buckling (e.g. Tikoff \& Maxson, 2001); (4) basal traction from the subducting slab (English, Johnston \& Wang, 2003); and (5) modification of the mantle flow in the corner beneath the cordillera (Hardebol et al. 2009; Jones et al. 2011). As well as the development of large-scale structural features, the far-field stresses in the foreland basin are also recorded through the matrix-scale damage (e.g. Weil \& Yonkee, 2012). Such finite strain is most often recorded in the undeformed foreland previous to the building of macroscopic features, illustrating that the compressive stresses are already influencing the damage of the foreland sedimentary sequence at the time macroscopic structures are formed (Weil \& Yonkee, 2012).

Considering the Southern Andes and the particular case of the Malargue Fold-Thrust Belt, a systematically compressive regime recorded in the development of inverted basement structures in the foreland basin (Strecker et al. 2011; this study), in the transmission of the crustal shortening in the intrabelt sedimentary cover (Branellec et al. 2015a, Branellec et al. this issue) and in the record by meso- and microscale strain indicators such as fracture sets and matrix-scale strain (Branellec et al. 2015b) is suggested. This pattern of deformation is also clearly evidenced further north in the Sierra Pampeanas (e.g. Strecker et al. 2011), defined as a 'broken foreland', related to the evolution of the coupling between the subducting pacific slab and the Cordillera, transmitted through the progressive thickening of the lower crust and rooting of crustal-scale thrust at the base of the fragile crust (Folguera et al. 2009; G. Messager, unpub. PhD thesis, Université de Pau et des pays de l'Adour, 2010).

\section{Conclusion}

We have reported two new forms of geomorphic evidence of active deformation along the eastern border of the San Rafael Block: (1) the uplift of an alluvial terrace remnant above the Las Malvinas Fault; and (2) the folding of a fan above the Cerro Negro Fault. Depending on the erosion rate, the cosmogenic dating of these markers allows us to put forward a range of uplift rates and to estimate the associated slip rates. Based on the topographic signature of these faults, we quantified their seismogenic potential and propose that these faults can possibly account for major seismic events including the Villa Atuel earthquake of 1929. Our observations also show that compressive deformation prevailed during Plio-Pleistocene times. At the larger scale, the fact the SRB is currently uplifting gave us some indications about the mode of deformation propagation between $34^{\circ} \mathrm{S}$ and $36^{\circ} \mathrm{S}$ which is characterized by the migration of deformation far away within the foreland, a common feature of broken forelands (Strecker et al. 2011).

Acknowledgements. The authors are very grateful to the Total group and Total Austral for financial support and field logistics. Authors also thank Michel Sébrier and one anonymous reviewer for their comments and suggestions which substantially improved the paper.

\section{References}

ALLMENDINGER, R. W. 1998. Inverse and forward numerical modeling of trishear fault-propagation folds. Tectonics 17(4), 640-56.

Allmendinger, R. W. \& SHAW, J. H. 2000. Estimation of fault propagation distance from fold shape: implications for earthquake hazard assessment. Geology 28(12), 1099-102.

Baker, S. E., Gosse, J. C., McDonald, E. V., Evenson, E. B. \& MARTínEZ, O. 2009. Quaternary history of the piedmont reach of Río Diamante, Argentina. Journal of South American Earth Sciences 28(1), 54-73.

Bastias, H., Tello, G., Perucca, L., Paredes, J. D. D. \& RAMOS, V. 1993. Peligro sísmico y neotectónica. In 122 Congreso Geológico Argentino Congreso de Exploración de Hidrocarburos.

Bermúdez, A., Delpino, D., Frey, F. \& SAAL, A. 1993. Los basaltos de retroarco extraandinos. In Congreso Geológico Argentino pp. 161-72.

Bernard, S., Avouac, J. P., Dominguez, S. \& Simoes, M. 2007. Kinematics of fault-related folding derived from a sandbox experiment. Journal of Geophysical Research: Solid Earth (1978-2012) 112(B3), doi: 10.1029/2005JB004149.

Branellec, M., Callot, J. P., Aubourg, C., Nivière, B. \& RiNGENBACH, J. C. 2015a. Matrix deformation in a basement-involved fold-and-thrust-belt: a case study in the central Andes, Malargüe (Argentina). Tectonophysics 658, 186-205.

Branellec, M., CAllot, J. P., NivièRe, B. \& RingenBaCh, J. C. 2015b. The fracture network, a proxy for mesoscale deformation: constraints on layer parallel shortening history from the Malargüe fold and thrust belt, Argentina. Tectonics 34(4), 2014TC003738.

Branellec, M., NivièRe, B., CALlot, J. P. \& RingenBaCh, J. C. 2016. Mechanisms of basin contraction and reactivation in the basement-involved Malargue foldand-thrust belt, Central Andes (34-36 S). Geological Magazine 153(5-6), doi: 10.1017/S0016756816000315.

Chamberlin, R. T. 1910. The Appalachian folds of central Pennsylvania. Journal of Geology 18(3), 228-51.

Cisneros, H. \& BASTÍAs, H. 1993. Neotectónica del borde oriental del bloque de San Rafael. In XII Congreso Geológico Argentino, Mendoza. Actas III, pp. 270-76.

Cisneros, H., ORMEÑO, P. \& BASTIAS, H. 1989. Fallas cuaternarias en el sur mendocino y su posible relación con el sismo de 1929. In Reunión de Fallas Activas del NOA, San Juan. 1(58-62). 
CobBold, P. R. \& Rossello, E. A. 2003. Aptian to recent compressional deformation, foothills of the Neuquén Basin, Argentina. Marine and Petroleum Geology 20(5), 429-43.

CortÉS, J. \& SRUOGA, P. 1998. Zonas de fractura cuaternarias y volcanismo asociado en el piedemonte de la Cordillera Frontal (34 30' LS), Argentina. In Actas X Congreso Latinoamericano de Geología y Actas VI Congreso Nacional de Geología Económica, Buenos Aires. Vol II, pp. 116-21.

Costa, C. H., Ahumada, E. A., Vázquez, F. R. \& KRÖHLING, D. M. 2015. Holocene shortening rates of an Andean-front thrust, Southern Precordillera, Argentina. Tectonophysics 664, 191-201.

Costa, C., Cisneros, H., Salvarredi, J. \& Gallucci, A. 2004. Nuevos datos y reconsideraciones sobre la neotectónica del margen oriental del bloque de San Rafael. In 12 Reunión sobre Microtectónica y Geología Estructural, Cafayate. Resúmenes 7.

Costa, C., Cisneros, H., Salvarredi, J. \& Gallucci, A. 2006. La neotectónica del margen oriental del bloque de San Rafael: Nuevas consideraciones. Asociación Geológica Argentina, Serie D: Publicación Especial 6, 33-40.

CRIADO RoQUÉ, P. \& IBAÑEZ, G. 1979. Provincia geológica Sanrafaelino-Pampeana. In Geología Regional Argentina. Córdoba: Academia Nacional de Ciencias, 1, 83786.

DeCELLES, P. G. 2004. Late Jurassic to Eocene evolution of the Cordilleran thrust belt and foreland basin system, western USA. American Journal of Science 304(2), 105-68.

DESILETS, D. \& ZREDA, M. 2003. Spatial and temporal distribution of secondary cosmic-ray nucleon intensities and applications to in situ cosmogenic dating. Earth and Planetary Science Letters 206(1), 21-42.

Desilets, D., ZREDA, M. \& PRABU, T. 2006. Extended scaling factors for in situ cosmogenic nuclides: new measurements at low latitude. Earth and Planetary Science Letters 246(3), 265-76.

DUNAI, T. 2001. Influence of secular variation of the geomagnetic field on production rates of in situ produced cosmogenic nuclides. Earth and Planetary Science Letters 193(1), 197-212.

English, J. M., Johnston, S. T. \& WANG, K. 2003. Thermal modelling of the Laramide orogeny: testing the flatslab subduction hypothesis. Earth and Planetary Science Letters 214(3), 619-32.

EPARD, J.-L. \& GROSHONG JR, R. H. 1993. Excess area and depth to detachment. AAPG Bulletin 77(8), 1291-302.

ERSLEV, E. A. 1991. Trishear fault-propagation folding. Geo$\log y$ 19(6), 617-20.

Folguera, A., BOTTESI, G., DUdDY, I., MARTíN-GONZÁLEZ, F., ORTS, D., SAGRIPANTI, L., ROJAS VERA, E. \& RAMOS, V. A. 2015. Exhumation of the Neuquén Basin in the southern Central Andes (Malargüe fold and thrust belt) from field data and low-temperature thermochronology. Journal of South American Earth Sciences 64(2), 38198.

Folguera, A., Bottesi, G., Zapata, T. \& Ramos, V. A. 2008. Crustal collapse in the Andean backarc since 2 Ma: Tromen volcanic plateau, Southern Central Andes (36 40'-37 30' S). Tectonophysics 459(1), 140-60.

Folguera, A., Introcaso, A., Giménez, M., Ruiz, F., Martinez, P., Tunstall, C., García Morabito, E. \& RAmos, V. A. 2007. Crustal attenuation in the Southern Andean retroarc (38-39 30' S) determined from tectonic and gravimetric studies: the Lonco-Luán asthenospheric anomaly. Tectonophysics 439(1), 129-47.
Folguera, A., NARAnjo, J. A., Orihashi, Y., Sumino, H., NagaO, K., Polanco, E. \& Ramos, V. A. 2009. Retroarc volcanism in the northern San Rafael Block (34 ${ }^{\circ}$ $\left.35^{\circ} 30^{\prime} \mathrm{S}\right)$, southern Central Andes: Occurrence, age, and tectonic setting. Journal of Volcanology and Geothermal Research 186(3-4), 169-85.

Folguera, A., ZAPATA, T. \& RAMOS, V. A. 2006. Late Cenozoic extension and the evolution of the Neuquén Andes. Geological Society of America Special Papers 407, 26785.

Forasiepi, A. M., Martinelli, A. G., DE la Fuente, M., DiEgueZ, S. \& Bond, M. 2011. Notes on the Paleontology and Stratigraphy of the Aisol Formation (Neogene, San Rafael, Mendoza Province): New Evidences. Salta: SCS Publisher.

Galland, O., Hallot, E., CobBold, P. R., RufFet, G. \& DE BREMOND D'ARS, J. 2007. Volcanism in a compressional Andean setting: A structural and geochronological study of Tromen volcano (Neuquén province, Argentina). Tectonics 26(4), doi: 10.1029/2006tc002011.

Giambiagi, L., BeChis, F., GARCÍA, V. \& ClARK, A. H. 2008. Temporal and spatial relationships of thick- and thinskinned deformation: a case study from the Malargüe fold-and-thrust belt, southern Central Andes. Tectonophysics 459(1-4), 123-39.

GonZÁLEZ DíAZ, E. F. 1972. Descripción geológica de la Hoja 27d, San Rafael, provincia de Mendoza. Servicio Nacional Minero Geológico, Boletín 132, 1127.

Gürer, D., Galland, O., Corfu, F., Leanza, H. A. \& SASSIER, C. 2016. Structure and evolution of volcanic plumbing systems in fold-and-thrust belts: A case study of the Cerro Negro de Tricao Malal, Neuquén Province, Argentina. Geological Society of America Bulletin 128(1-2), 315-31.

Guzmán, C., Cristallini, E. \& Bottesi, G. 2007. Contemporary stress orientations in the Andean retroarc between $34^{\circ} \mathrm{S}$ and $39^{\circ} \mathrm{S}$ from borehole breakout analysis. Tectonics 26(3), doi: 10.1029/2006tc001958.

Hardebol, N. J., Callot, J. P., Bertotti, G. \& Faure, J. L. 2009. Burial and temperature evolution in thrust belt systems: Sedimentary and thrust sheet loading in the $\mathrm{SE}$ Canadian Cordillera. Tectonics 28(3), TC3003.

Huyghe, D., Bonnel, C., Nivière, B., FAsentieuX, B. \& HerVOUËT, Y. 2015. Neogene tectonostratigraphic history of the southern Neuquén basin $\left(39^{\circ}-40^{\circ} 30^{\prime} \mathrm{S}\right.$, Argentina): implications for foreland basin evolution. Basin Research 27, 613-35.

Huyghe, D., NiviÈre, B. \& BonNel, C. 2015. Geomorphologic evidence for Plio-Quaternary shortening in the southern Neuquén basin ( $40^{\circ} \mathrm{S}$, Argentina). Terra Nova 27(6), 426-32.

Jones, C. H., Farmer, G. L., SAgeman, B. \& Zhong, S. 2011. Hydrodynamic mechanism for the Laramide orogeny. Geosphere 7(1), 183-201.

KAY, S. 2002. Tertiary to Recent transient shallow subduction zones in the Central and Southern Andes. In Proceedings Congreso Geológico Argentino. El Calafate, 15, 28283.

Kay, S. M., Burns, W. M., Copeland, P. \& Mancilla, O. 2006. Upper Cretaceous to Holocene magmatism and evidence for transient Miocene shallowing of the Andean subduction zone under the northern Neuquén Basin. In Evolution of an Andean Margin: A Tectonic and Magmatic View from the Andes to the Neuquén Basin $\left(35^{\circ}-39^{\circ}\right.$ S lat) (eds S. M. Kay \& V. A. Ramos), pp. 19-60. Geological Society of America, Special Paper no. 407. 
Kendrick, E. C., Bevis, M., Smalley, R., Cifuentes, O. \& GALBAN, F. 1999. Current rates of convergence across the central Andes: Estimates from continuous GPS observations. Geophysical Research Letters 26(5), 54144.

KHAZARADZE, G. 2003. Short- and long-term effects of GPS measured crustal deformation rates along the south central Andes. Journal of Geophysical Research 108(B6), doi: 10.1029/2002jb001879.

KostadinOfF, J. \& Llambías, E. 2002. Cuencas sedimentarias en el subsuelo de la provincia de La Pampa. In Congreso de Exploración y Desarrollo de Hidrocarburos. IAPG, Mar del Plata.

KUSIAK, M. E. 1993. Nuevo afloramientos basales de la Formación Puesto Viejo al suroeste de la presa Valle Grande, río Atuel, San Rafael - Mendoza. In Actas $12^{\circ}$ Congreso Geologico Argentino y $2^{\circ}$ Congreso de Exploracion de Hicrocarburos. Mendoza, 2, 63-70.

LAL, D. 1991. Cosmic ray labeling of erosion surfaces: in situ nuclide production rates and erosion models. Earth and Planetary Science Letters 104(2-4), 424-39.

LARA, L. E. \& Folguera, A. 2006. The Pliocene to Quaternary narrowing of the Southern Andean volcanic arc between 37 and $41 \mathrm{~S}$ latitude. In Evolution of an Andean Margin: A Tectonic and Magmatic View from the Andes to the Neuquén Basin $\left(35^{\circ}-39^{\circ}\right.$ S lat) (eds S. M. Kay \& V. A. Ramos), pp. 299-315. Geological Society of America, Special Paper no. 407.

Lifton, N. A., Bieber, J. W., Clem, J. M., Duldig, M. L., Evenson, P., Humble, J. E. \& Pyle, R. 2005. Addressing solar modulation and long-term uncertainties in scaling secondary cosmic rays for in situ cosmogenic nuclide applications. Earth and Planetary Science Letters 239(1), 140-61.

LUCERO, C. 2002. Sistema estructural Aisol-Tordillo, bloque de San Rafael. In $15^{\circ}$ Congreso Geológico Argentino. El Calafate 1, 363-68.

LuCERO, C. \& PAREDES, J. 1999. Fallamiento rumbodeslizante en la falla Aisol, Bloque de San Rafael, Mendoza. In XIV Congreso Geológico Argentino. Salta, Actas I, 263-66.

LÜNKENHEIMER, F. 1929. El terremoto surmendocino del 30 de mayo de 1929. Contribuciones Geofísicas 3(2).

Lupari, M. N., SPAgnotTo, S. L., NACif, S. V., YaCANTE, G., GARcía, H. P. A., Lince-Klinger, F., SÁNCHEZ, M. A. \& TRIEP, E. 2015. Sismicidad localizada en la zona del Bloque San Rafael, Argentina. Revista Mexicana de Ciencias Geológicas 32(2), 190-202.

MANCEDA, R. \& FigUEROA, D. 1995. Inversion of the Mesozoic Neuquén rift in the Malargüe fold and thrust belt, Mendoza, Argentina. In Petroleum Basins of South America (eds A. J. Tankard, R. Suarez Soruco \& H. J. Welsink). American Association of Petroleum Geologists, Memoir no. 42.

MARQUES, F. \& CoBBOLD, P. 2002. Topography as a major factor in the development of arcuate thrust belts: insights from sandbox experiments. Tectonophysics 348(4), 24768.

MCQuARrie, N. \& ChASE, C. G. 2000. Raising the Colorado plateau. Geology 28(1), 91-4.

Messager, G., Nivière, B., Lacan, P., Hervouët, Y. \& XAVIER, J.-P. 2014. Plio-Quaternary thin-skinned tectonics along the crustal front flexure of the southern Central Andes: a record of the regional stress regime or of local tectonic-driven gravitational processes? International Journal of Earth Sciences 103(3), 929-51.

Messager, G., Nivière, B., Martinod, J., LACAN, P. \& XAVIER, J. P. 2010. Geomorphic evidence for Plio-
Quaternary compression in the Andean foothills of the southern Neuquén Basin, Argentina. Tectonics 29(4), doi: $10.1029 / 2009$ tc002609.

MoretTI, I. \& CALLOT, J. P. 2012. Area, length and thickness conservation: Dogma or reality? Journal of Structural Geology 41(0), 64-75.

Pepin, E., Carretier, S., Hérail, G., Regard, V., Charrier, R., FArÍAs, M., García, V. \& Giambiagi, L. 2013. Pleistocene landscape entrenchment: a geomorphological mountain to foreland field case, the Las Tunas system, Argentina. Basin Research 25(6), 61337.

PerucCA, L. P. \& MoreIras, S. M. 2006. Liquefaction phenomena associated with historical earthquakes in San Juan and Mendoza Provinces, Argentina. Quaternary International 158(1), 96-109.

PortenGA, E. W. \& BIERMAN, P. R. 2011. Understanding Earth's eroding surface with 10 Be. GSA Today 21(8), 4-10.

Ramos, V. A. 2010. The Grenville-age basement of the Andes. Journal of South American Earth Sciences 29(1), 77-91.

Ramos, V. A. \& Folguera, A. 2005. Tectonic evolution of the Andes of Neuquén: constraints derived from the magmatic arc and foreland deformation. In The Neuquén Basin: A Case Study in Sequence Stratigraphy and Basin Dynamics (eds G. D. Veiga, L. A. Spalletti, J. A. Howell \& E. Schwarz), pp. 15-35. Geological Society of London, Special Publication no. 252.

RAMOS, V. A. \& KAY, S. M. 1991. Triassic rifting and associated basalts in the Cuyo basin, central Argentina. In $\mathrm{An}$ dean Magmatism and its Tectonic Setting (eds R. S. Harmon \& C. W. Rapela), pp. 79-92. Geological Society of America, Special Paper no. 265.

Ramos, V. A. \& KAY, S. M. 2006. Overview of the tectonic evolution of the southern Central Andes of Mendoza and Neuquén (35-39 S latitude). In Evolution of an Andean Margin: A Tectonic and Magmatic View from the Andes to the Neuquén Basin $\left(35^{\circ}-39^{\circ}\right.$ S lat) (eds S. M. Kay \& V. A. Ramos), pp. 342. Geological Society of America, Special Paper no. 407.

Ramos, V. A., ZaPATA, T., CRistallini, E. \& Introcaso, A. 2004. The Andean Thrust System: latitudinal variations in structural styles and orogenic shortening. In Thrust Tectonics and Hydrocarbon Systems (ed. K. R. McClay), pp. 30-50. American Association of Petroleum Geologists, Memoir no. 82.

SAgRipanti, L., VERA, E. A. R., GianNi, G. M., Folguera, A., Harvey, J. E., Farías, M. \& Ramos, V. A. 2015. Neotectonic reactivation of the western section of the Malargüe fold and thrust belt (Tromen volcanic plateau, Southern Central Andes). Geomorphology 232, 164-81.

Sepúlveda, E., CARPio, F., Regairaz, M., ZÁrate, M. \& ZANETTINI, J. 2000. Hoja Geológica 3569-II, San Rafael. Servicio Geológico Minero Argentino Boletín, 268.

SiAme, L. L., SÉBrier, M., Bellier, O., Bourlès, D., Costa, C., Ahumada, E. A., Gardini, C. E. \& CisNeros, H. 2015. Active basement uplift of Sierra Pie de Palo (Northwestern Argentina): rates and inception from $10 \mathrm{Be}$ cosmogenic nuclide concentrations. Tectonics 34(6), 1129-53.

Simoes, M., Avouac, J. P., Beyssac, O., Goffé, B., FARLey, K. A. \& CHEN, Y. G. 2007. Mountain building in Taiwan: a thermokinematic model. Journal of Geophysical Research: Solid Earth (1978-2012) 112(B11), doi: 10.1029/2006jb004824.

SteIN, R. S. \& YeATS, R. S. 1989. Hidden earthquakes. Scientific American 260(6), 48-57. 
STONE, D. S. 1993. Basement-involved thrust-generated folds as seismically imaged in the subsurface of the central Rocky Mountain foreland. In Laramide Basement Deformation in the Rocky Mountain Foreland of the Western United States (eds C. J. Schmidt, R. B. Chase \& E. A. Erslev), pp. 271-318. Geological Society of America, Special Paper no. 280.

StONE, J. O. 2000. Air pressure and cosmogenic isotope production. Journal of Geophysical Research: Solid Earth 105(B10), 23753-59.

Strecker, M. R., Hilley, G. E., Bookhagen, B. \& SOBEL, E. R. 2011. Structural, geomorphic, and depositional characteristics of contiguous and broken foreland basins: examples from the eastern flanks of the Central Andes in Bolivia and NW Argentina. In Tectonics of Sedimentary Basins (eds C. Busby \& A. A. Perez), 508-21. Chichester: John Wiley \& Sons, Ltd.
TIKOFF, B. \& MAXSON, J. 2001. Lithospheric buckling of the Laramide foreland during Late Cretaceous and Paleogene, western United States. Rocky Mountain Geology 36(1), 13-35.

WeIL, A. B. \& YonKeE, W. A. 2012. Layer-parallel shortening across the Sevier fold-thrust belt and Laramide foreland of Wyoming: spatial and temporal evolution of a complex geodynamic system. Earth and Planetary Science Letters 357, 405-20.

Wells, D. L. \& COPPERSMith, K. J. 1994. New empirical relationships among magnitude, rupture length, rupture width, rupture area, and surface displacement. Bulletin of the Seismological Society of America 84(4), 9741002.

Zehnder, A. T. \& ALLmendinger, R. W. 2000. Velocity field for the trishear model. Journal of Structural Geology 22(8), 1009-14. 